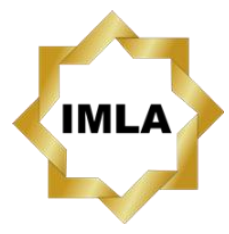

Available online:

http://journal.imla.or.id/index.php/arabi

Arabi : Journal of Arabic Studies, 5 (2), 2020, 153-165

DOI: http://dx.doi.org/10.24865/ajas.v5i2.247

\title{
THE ONTOLOGY OF ARABIC CURRICULUM AT PESANTREN ATTAHDZIB JOMBANG
}

\author{
Ahmad Nurcholis, Mochamad Chobir Sirad, \\ Budi Harianto, Syaikhu Ihsan Hidayatullah \\ Institut Agama Islam Negeri Tulungagung, Indonesia \\ E-mail : cholisahmad87@gmail.com
}

\begin{abstract}
Some pesantrens have accommodated the madrasah or formal school education programs, both the curriculum and the learning methods. One of them is pesantren Attahdzib. This article aimed to describe, analyze, and interpret the ontology of Attahdzib Islamic boarding school curriculum, the process of implementing the curriculum, and the problems of its implementation. It was a qualitative research with descriptive analysis. The results showed that the the curriculum was implemented through some methods such as sorogan, bandongan or wetonan, and memorization. There were 2 types of education systems established in pesantren Attahdzib, namely Diniyah education, and formal education. The problems faced in the implementation of curriculum were some teachers' disciplinary problem, the learning evaluation that sometimes considered hard and burden on students, and the formal schools' extraactivities that sometimes obstructed the pesantren's teaching and learning process.
\end{abstract}

Keywords: ontology, curriculum, Arabic

\begin{abstract}
Abstrak
Beberapa pesantren telah mengakomodasi program pendidikan madrasah mereka, baik kurikulum maupun metode pembelajarannya. Salah satu dari pesantren tersebut adalah pesantren Attahdzib. Artikel ini bertujuan untuk mendeskripsikan, menganalisis, dan menginterpretasi secara ontologis kurikulum pesantren Attahdzib, proses implementasi kurikulum Attahdzib, serta problematika yang dihadapinya dalam menerapkan kurikulum. Pendekatan penelitian ini menggunakan desain kualitatif dengan metode deskriptif analisis. Sedangkan hasil penelitian menunjukkan bahwa kurikulum pesantren Attahdzib yaitu: sorogan, bandongan atau wetonan, dan hafalan. Secara global, sistem pendidikan atau pembelajaran yang diterapkan di pesantren Attahdzib ada 2 jenis, yaitu: 1) Pendidikan Diniyah; dan 2) Pendidikan formal, serta kegiatan ekstra kurikuler. Problematika yang dihadapi oleh pesantren Attahdzib dalam menerapkan kurikulum yaitu pendidik yang kurang disiplin, melakukan evaluasi pembelajaran yang dianggap membebani peserta didik, dan kegiatan ekstra di sekolah formal yang terkadang mengganggu jalannya proses pembelajaran di pesantren Attahdzib.
\end{abstract}

Kata Kunci: ontologi, kurikulum, bahasa Arab 


\section{Arabi : Journal of Arabic Studies}

\section{Introduction}

Curriculum is an indispensable tool for achieving an education purpose. As a guideline in the implementation of learning, the curriculum determines the success of an education system. Thus, the curriculum can be referred to as a driving force in the learning process at various levels and types of learning. Besides, the curriculum can also be described as a written document as a result of mutual agreement between the curriculum compilers and education policyholders with the community that covers a certain scope, whether a school, district, province, or the whole country. However, the curriculum is often not able to keep up with the pace of development of society. Therefore, the development and improvement of the curriculum must always be carried out continuously. In the context of education in pesantren, according to Nurcholish Madjid (1985), the curriculum term is unknown in the world of pesantren, especially during the pre-independence era, even though the education material the skills have been taught at pesantren. Most pesantrens do not formulate the basis and objectives of pesantren explicitly in the form of curriculum. The objectives of pesantren education are determined by Kiai's (leader of pesantren) policy, according to the development of pesantren (S. Nasution, 1995).

Learning Arabic in pesantren needs to be paid attention by Indonesian people, especially Muslims because Arabic is a language necessary for understanding Islam, particularly for understanding Al-Quran which is the basic of Muslims. The implementation of worship that uses Arabic, habits, and books of previous ulama now often become the basis as the implementation of Islamic's sharia.

Unfortunately, the dominance of pesantren in the world of education began to decline drastically after the 1950s. One of the factors causing this was that modern jobs began to open which received training exercises in public schools. This has led to a decrease in the interest of young people in pesantren education compared to general schools, while the government's attention since the proclamation of the national education system.

In responding to this problem, many traditional pesantrens have included general lessons or founded formal schools to offset the public interest in existing public schools. The problem that arises then is whether pesantren in determining curriculum must merge with the demands of the present day, or rather, it must be able to maintain it as a characteristic of pesantren to actualize their existence amidst the demands of society.

This paper is focused on discussing about how traditional pesantrens maintain their teaching style and curriculum, but still be able to actualize its existence towards the current demands of the community. Pesantren Attahdzib combines two curriculums, namely pesantren salaf curriculum and public school curriculum that are side by side and strengthen one another.

The importance of the Arabic language learning curriculum was also stated by Roviin (2018) in his research Development of the Arabic Language Curriculum in Madrasah: Analysis of Approaches, Models, and Procedures. He found that in the context of Arabic learning in a madrasah, a deep understanding of the curriculum and its development are needed, mainly through a functional approach. Miftahur Rohman (2018) in his research Learning Arabic in Madrasah Aliyah on Curriculum 2013 Perspective: A Juridical Review found that a curriculum has components that must be considered and the learning activities are the implementation to fulfill these components.

Fulfilling the curriculum effectively in the pesantren environment seems to be inseparable from the problem. This was discovered by Habibi (2019) in his research on the Integration of the Traditional and Modern Islamic Boarding School Curriculum in the Madrasah Aliyah Religious Program. It was found that the traditional pesantren curriculum places more emphasis on grammar while modern Pesantren places more emphasis on language (in the sense of active language).

Himmah and Amrullah (2017) in their research Development of the Mu'adalah Islamic Boarding School Curriculum: Case Study in al-Kausar Islamic Boarding School of Banyuwangi emphasizes their research on Arabic curriculum planning in the pesantren which starts from setting

Vol. 5 No. 2 | $154-165$

Copyright ( 2020 | ARABI | p-ISSN 2548-6616 | e-ISSN 2548-6624 
the objectives, materials, methods, and evaluations. Abdul Wahab (2016) in his research Standardization of Arabic Language Education Curriculum at State Islamic Religious Universities revealed the importance of the epistemology of linguistics development to make the Arabic reviewers can understand Arabic "scientific maps" clearly and distinctively so the development of Arabic education and learning curriculum can be carried out following the needs, scientific demands, and the times.

Based on some of the studies above, this article aims to describe, analyze, and interpret the ontology of pesantren Attahdzib curriculum, the process of implementing the curriculum, and the problems faced by the Attahdzib pesantren in its implementation.

\section{Method}

This study used a qualitative approach. This was an inquiry process of understanding based on paradigms of The Ontology of Arabic Curriculum at Pesantren Attahdzib Jombang. The research method was a theoretical orientation or perspective analysis method with a phenomenological approach. The researchers tried to show the meaning behind reality, so the involvement of subjects with objects was required, and subjects acted as instruments to uncover the meaning behind a reality according to recognition, opinions, feelings, and willingness of the object (Matthew B. Miles and A. Michael Huberman, 2012).

The research site was Pesantren Attahdzib Jombang. The research instrument was the researcher himself. The researchers played role as planners, executors of data collection, analysis, data interpreters, and finally become the reporter of the research result. The data sources were informants, activities, locations, documents relating to the phenomenon. The data were collected through in-depth interviews, participant-observers, and documentation (Lexy J. Moleong, 2002).

Researchers used Miles and Huberman's (2012) data analysis which was carried out interactively and continuously until the data saturation was achieved. Activities in the analysis included data reduction, data display, and drawing conclusions and verification. While analyzing this data, researchers used inductive, deductive, and comparative methods.

After the data was collected, then the researcher administered the validity test. Besides, researchers also used in-depth observation techniques and triangulation. And also, with the peer debriefing method, they discussed the data that has been collected with parties who have relevant knowledge and expertise, both colleagues and research partners (Suharsimi Arikunto, 1997).

\section{Result and Discussion}

\section{The Nature of Pesantren Curriculum}

The term curriculum comes from the Latin language, curriculum whose original meaning is "a running course, or rase course and in French, it is derived from the word courier which means to run" (Hasan Basri, 2009). This shows that the term curriculum was derived from the field of sports in ancient Roman times which implies a distance that must be traveled by runners from the start to finish. In the context of Islamic education, the term curriculum is better known as "manhaj" which means as a clear path traveled by teacher and student in developing knowledge, skills, and attitudes (Ramayulis and Samsul Nizar, 2009).

In the Webster dictionary, the curriculum is currently defined in the way: "the course and class activities in which children and youth engage; the total range of classes out of class experiences sponsored by the school; and the total life experience of the learner." Regarding this definition, Ahmad Tafsir explained that curriculum can be interpreted into two types: first, several subjects that must be taken or studied by students in schools or colleges that obtain a certain diploma; second, some subjects offered by an educational institution or department (Mohamad Ali, 2009).

Ideally, a curriculum is designed to lead from ideas that are selected in-depth, then poured into written documents (plans) clearly, then implemented professionally in the learning process, to 


\section{Arabi : Journal of Arabic Studies}

obtain the desired maximum results (Tsuroyya, 2017). In practice the four dimensions are not always in line, the ideas may not be contained in the plan and directly implemented in learning, this is common, for example, the ideas/views of a teacher that are not contained in the document implemented (process) and affect learning outcomes, so that the term hidden curriculum (Salamah, 2016).

From some definitions above it can be understood that the curriculum in the modern definition is more often interpreted broadly, not only as a subject but includes all activities and experiences that are the responsibility of the school (Thohir, 2017). In this case, it is not separated between intra-curricular activities and extracurricular activities. Although the understanding and view on the curriculum change from traditional to modern or narrow to broad, the concept of traditional or narrow curriculum does not mean that it has been abandoned altogether. (Saifuddin, 2015)

Education practitioner generally still uses the concept of the curriculum, besides, to implement a modern curriculum (Salamah, 2016). Philosophically, the nature of the curriculum is a model referred to by education to shape the image of an education institution by realizing agreed education goals. Therefore, every educational institution has its curriculum (Hasan Basri, 2009).

Similarly, pesantren as one of the non-formal education institutions must have a goal to be achieved in educating students. And to realize these goals a curriculum is formed which is considered as a very important bridge to reach the endpoint of a journey for the success of a destination of pesantren. However, pesantren that follow the salafi (traditional) pattern, the curriculum may not have been well formulated. (Hajjaj, 2017)

In its development, pesantren experiences rapid changes. There is even a tendency to show trends. Some pesantrens have developed their institutions by opening madrasah system, public schools, and some of them have opened a kind of vocational education institution, such as agriculture, ranch, engineering, and so on (Hanun Asrohah, 1999). Madrasah or schools that are held in pesantren use the same curriculum as those in madrasah or other schools that have been standardized by The Ministry of Religious Affairs and The Ministry of Education And Culture. While other non-formal education institutions organized by pesantren, the curriculum is prepared by the organizers or pesantren concerned. The curriculum at pesantren salafiyah is not in the form of syllabus description but in the form of books that are taught to the students. (Ma'arif dan Rofiq, 2018)

The books used are usually Kitab Kuning or kutub al-salaf. Yellow represents the color because generally the books are printed on yellow paper. Among some pesantrens, the term kitab klasik is also used to refer to the same book. The books are generally not given harakat, so it is also called kitab gundul. These are also called ancient books, because of the vast history of time since they were compiled and published until now. In the Islamic intellectual tradition, the mention of the terms of ulama works' books is distinguished based on the period or the format of the writing. (Abdurrahman, 2017)

The teaching of these books, although the level of the material taught is sometimes repetitive. The gaps are intended for deepening and expansion, so students' mastery of content or material is more stable. This has become one of the characteristics of learning organization in pesantren. In the implementation of the intersection is not absolute, it could be pesantren additional or take steps to innovate, for example by teaching more popular books, but more in preparation, so it is more effective for students to master the material (Ahmad Saifuddin, 2016).

\section{The Implementation of Pesantren Curriculum}

As an educational institution that guides the santri (students) to be a human who is useful in worldly life and ukhrawi, pesantren in the context of achieving education goals cannot be separated from the curriculum that is designed. Therefore, it is not wrong if it is deemed necessary to evaluate the pesantren curriculum as well as efforts to develop it. Speaking of curriculum 
development, in the context of this paper the emphasis is on the development model which can at least be classified into four aspects, namely education goals, learning materials, learning processes, and assessments (S. Nasution, 1995). Therefore, according to these four things that are explained this can be considered for implementation in the world of pesantren education.

\section{a. The Objectives of Pesantren Education}

As already mentioned that the term curriculum is indeed not very well known in the world of pesantren even though the material already exists in the practice of teaching, spiritual guidance, and training skills in daily life at pesantren. That is why, pesantren generally do not explicitly formulate the basis and objectives of education nor implement it sharply in the curriculum in learning plans, and learning periods. In this case, Nurcholish Madjid indicated that the objectives of pesantren education were generally left to the process of improvisation according to the development of pesantren which was chosen by Kiai or together with his assistant intuitively (Nurcholis Madjid, 1985).

In the meantime, it is not a weakness when pesantren differs from one another in formulating their education goals. Zamakhsyari Dhofier (1982) detailed the education objectives of pesantren which included elevating morals, training and enhancing spirit, respecting spiritual and human values, teaching honest and moral behavior, and preparing students for simple and good lives. Further, he emphasized that the purpose of pesantren is not to pursue the interests of power, money, and worldly grandeur, but rather that learning is solely an obligation and dedication to God.

\section{b. Learning Materials}

Zamakhsyari (1982) mentions that all the classic books taught by pesantren are classified into eight groups: 1. Nahwu (syntac) and Sharaf(Morphology); 2. Fiqih; 3.Ushul Fiqih; 4. Hadits; 5. Tafsir; 6. Tauhid; 7. Tasawuf and Akhlak; 8. Other branches such as Tarikh (history) and Balaghah. Those (kitab) are included the short books, medium to texts consisting of thick volumes. Everything can be classified into 3 groups, namely kitab dasar, kitab menengah, and kitab besar.

The elementary books represent the books that are studied at the beginning of entering the pesantren enrollment. From its size, this book is thin, consisting of simple lessons at the introductory stage such as Sullam Taufiq, Mabadi Fiqh, Arba'in Nanawiyah, etc. Intermediate books represent books that are taught at an advanced level, in terms of size this book is thicker and takes a long time to complete such as Tafsir Jalalain, Ihya Ulumuddin, etc. While the big book is kitab tafsir such as tafsir Al-Azhar, Al-Misbah, etc, this book is thick and can be printed in many volumes. All those books are studied to be taught and practiced.

From the series of knowledge taught, not all have the same weight of attention and deepening. There is pressure on certain teachings. For example, Tasawuf no longer dominates the curriculum. If at the beginning of the growth of pesantren, Tasawuf as a very dominant subject matter, then lately Tasawuf has been shifted by other subjects. As a result, Tasawuf attention began to weaken. The curriculum content above clearly shows that the most dominant material is language, then fiqih. Saridjo et al. mentioned that the knowledge that comes first is knowledge in Arabic (sharaf and the other ilmu alat) and knowledge related to daily sharia (fiqh, both relating to pray and muamala). In contrast, in recent developments, fiqh has become the most dominant science in pesantren (Mujamil Qomar, 2009).

Inevitably, fiqh among all branches of Islamic religion is usually considered the most important. Fiqh contains various concrete implications for individual and community daily practitioners. Fiqh explains forbidden and recommended actions. In pesantren, fiqh is usually the belle of all subjects. All pesantrens, of course, also teach Arabic (ilmu alat) and at least the basics of tauhid and akhlak. But this pesantren education consists of fiqh works.

Pesantren curriculum mentioned above needs to be added because there is an imbalance in it. It is seen that the study of fiqh is too strong, while the study of tafsir methods, hadith, and the 


\section{Arabi : Journal of Arabic Studies}

development of religious insights is less highlighted. Even though all pesantren consider that the source of the law is Quran, hadith, and qiyas, the source is not controlled by the students contextually. Therefore, in order not to be fixated on applied sciences, it is necessary to redefine the orientation of knowledge of insights such as history, philosophy and comparison of mazhab (muqãranat al-madzãhib). This improvement can at least empower the minds of students to become widespread in addition to reducing the dominance of fiqh and its consequences (Mujamil Qomar, 2009).

\section{c. Learning Process}

In general, learning in pesantren follows the traditional pattern, which is sorogan and the bandongan model. Both of these models are active Kiai and passive students. Technically sorogan model is individualized, students face the group one by one by bringing the book to be studied, while bandongan model (weton) is more classical teaching, students following the lesson by sitting around Kiai explaining the lesson in a scheduled. Both sorogan and bandongan models are carried out with the reading of the book which begins with the reading of tarjamah, syarah with grammatical analysis, morphological review, and sematic description. Kiai is as a reader and translator, not just reading the text, but also giving personal views (interpretation), both regarding the content and language. Both of these teaching models by some education experts are considered static and traditional. Even though sorogan and bandongan are considered static, it does not mean that they do not accept innovation. In fact, according to Suyoto, this method is a consequence of the service that is intended to be provided to students. Various efforts today to innovate do precisely lead to individual services to students. Sorogan method emphasizes someone's maturity and attention and skill (M. Dawam Rahardjo, 1988).

In the meantime, Mastuhu views that sorogan is a direct and intensive individual teaching method. In terms of education this method is a modern method because between kiai and students know each other closely, and the teacher has mastered the material that should be taught. Students also study and make preparations before. Thus the teacher already knows what material is suitable for students and what materials must be used specifically to deal with their st udents. Besides that, sorogan method is also carried out freely (no coercion), and free from obstacles informality (Mastuhu, 1988).

Thus, what is considered is not an attempt to change the method sorogan method to become a model of lectures as a modern education system, but to modify to be the latest sorogan (new style). Intended this latest sorogan is the practice of professors Mukti Ali so far. He taught postgraduate and medical education with sorogan method. Students are given assignments one by one at the scheduled face-to-face, after reading the discussion is held by way of dialogue and discussion until they get a clear understanding of the subject. According to Multi Ali, this method was quite successful, bearing in mind the reports of several students who had not mastered foreign languages either English or Arabic, eventually being able to master foreign languages (A. Mukti Ali, 1987).

\section{d. Assessment}

In general, pesantren which has not transplanted a modern education system is not familiar with evaluation systems. The increase in level is simply marked by the change in the book (kitab) being studied. The students measures and evaluates whether they has mastered the past material and can follow the lessons of the next book (kitab). The learning period is not determined to provide flexibility to students to leave pesantren after feeling satisfied with the knowledge they have gained and feel ready to go into the community. If the student is not satisfied, it is not wrong for him to move to another pesantren to explore his knowledge. The academic assessment is conducted by students themselves based on modern assessments because someone's academic ability about the competence of education outcomes is not determined based on the numbers provided by the teacher and formally recognized by the educational institution concerned, but determined by his ability to teach books (kitab) or knowledge that he has gained to others. In other 
words, the potential of pesantren graduates is directly determined by the community (Mastuhu, 1988).

According to Qodri A. Azizi (2000), a complete learning pattern that lasts for 24 hours is very effective in evaluation. Kyai is as an evaluator who can carry out an evaluation so that deviations can be minimized. According to him, it is easier for kyai to convey his knowledge and experience. The following are the roles and objectives of pesantren evaluation.

1) Making policies and decisions for the development of pesantren;

2) Assessing the results achieved by the students and the teachers or other teachers in pesantren;

3) Assessing the curriculum program, whether it is appropriate or not, relevant or not, too complicated or not;

4) Giving trust to pesantren to conduct self-evaluation. If this program is carried out continuously it will increase the accountability of pesantren;

5) Monitoring the use of funds, whether the funds used for various activities in pesantren has been used effectively or not;

6) To assess the professionalism of teachers/ coaches/ ustadz or ustadzah, whether they have sufficient competence or not;

7) To get input to improve the material and various programs run in pesantren.

\section{The Pattern of Arabic Curriculum at Pesantren}

The main standards that serve as benchmarks in modeling a curriculum are subject matter that is intra-curricular and the methods that are delivered, in the world of pesantren. Pesantren education pattern in terms of curriculum, according to Haidar Putra Daulay (2001) there are five patterns.

Pattern I, the subject matter given at pesantren is a subject sourced from kitab klasik. The delivery techniques with wetonan and sorogan does not use the classical system. Students are assessed and measured based on kitab they read, general subjects are not taught, do not prioritize diplomas, but the most important is the experience of the religious sciences they expect from studies through these kitab-kitab klasik.

Pattern II, the teaching and learning process carried out in a classical manner, where given skills material and organizational education. At a certain level, the students are given additional knowledge. Students are divided into several levels of education starting from the level of ibtidaiyah, tsanawiyah, aliyah. The methods used are sorogan, wetonan, memorising and bahtsul masa'il(deliberation).

Pattern III, in this pattern the subject matter has been supplemented with general lessons and added various types of education such as skills, sports, arts, and organizational education.

Pattern IV, this pattern focuses more on skills lessons other than religious subjects, where the skills are given with the aim as a provision in the lives of students after students graduate from boarding schools.

Pattern V, in this pattern the material taught in pesantren is as follows: a) Teaching kitab klasik, b) Madrasah education is held in pesantren, which is usually done at night and some in the morning. Besides teaching religious subjects, it also teaches general subjects. Where the boarding school curriculum is there are two parts. First, the curriculum is made by pesantren itself. Second, the curriculum from the government is modified by integrating it with religious subject matter; c) Skills and arts are also taught in various activities, such as arranging flowers, making calligraphy, tilawah, hadroh, and so on; d) Public schools, in pesantrens are also equipped with public schools. The general subject matter in public schools in pesantren, as a whole, is inseparable from the curriculum of the national education department. As for the material for religious studies arranged by the boarding school itself; e) Some well know pesantrens have even had a university or college that is still a foundation with pesantren. 


\section{Arabi : Journal of Arabic Studies}

Researchers found some institutions that have integrated curriculum, for example, the Islamic Education Institute of Al-Azhaar Trenggalek. As one of the oldest Islamic educational institutions in its town, this institution has successfully delivered its alumni abroad, continue studying at the best national institutions, and so on. Also, what the researchers often meet is one model that always be adopted by its alumni, which is the Modern Islamic Boarding School of Darussalam Gontor. All santri are emphasized to master Arabic and English for communication as well for understanding Islamic books.

The researchers believe that curriculum development likely to be sustainable following the advancement in information technology. The negative perception of the santri as students who have limited access to technological advances will be refuted by the santri who master technology.

\section{Pesantren Attahdzib}

This pesantren is located in Ngoro. It has a practical education model in 'ubudiyah, in addition to theories like other pesantren education models. This is implemented as an embodiment of the vision and mission of Pesantren Attahdzib. The vision of Pesantren Attahdzib is "to be a solid pesantren salaf with pillars of noble morals and spiritual-emotional-intellectual intelligence". While pesantren At-Tahdzib mission is to "produce a cadre of intellectuals who are "wali" and "wali" who are intellectual" the term "intellect" is intended to be able to master various sciences and be able to apply them. Whereas term "wali" is meant that his heart always recites $d z i k r$ to Allah Swt. and takhalluq bi akhlaqi Rasulillah Saw. This vision and mission are upheld on Islamic moral principles and noble morals (al akhlaq al karimah).

The objectives of pesantren Attahdzib are to support government programs in the fields of religion, education, social and culture; and Forming people who are devoted to Allah Swt. and Rasul, knowledge and good attitude, and sincere devotion to religion, homeland, nation, and country (Budi, 2020).

\section{Curriculum of Pesantren At-Tahdzib}

The dominance of pesantren in the world of education began to decline drastically after the $1950 \mathrm{~s}$, one of the factors was that modern jobs began to open which received training in public schools. This has led to a decrease in the interest of young people in pesantren education compared to general schools, while the attention of the government since the proclamation of the national education system.

In addressing this problem many traditional pesantrens have included general lessons or established formal schools, to offset the public interest in existing public schools. But pesantren still maintain the style and characteristics of traditional pesantren, but still able to actualize its existence towards the wishes of the community.

The researcher highly appreciates the curriculum developments that have been carried out by pesantren without losing the characteristics of traditional pesantren and being able to deal with the times and interests of the global community. This makes the pesantren exist until now and is more developed in the future (Albantani \& Madkur, 2018).

The curriculum contained in this Pesantren Attahdzib includes pattern V, the material taught at Pesantren Attahdzib is as follows: a) Teaching kitab klasik, such as kitab kuning, b) In pesantren there is a diniyah recitation, which is usually held at night, but some are held in the morning. Besides teaching religious lessons, it also teaches general subjects. Pesantren curriculum is there are two parts. First, the curriculum is created by pesantren itself. Second, government curriculum implemented in formal schools under IHSANNIAT foundation; c) Skills and arts are also taught in various activities such as: making calligraphy, tilawah, hadrah, and so on; d) Public schools, in pesantren is also equipped with public schools. The general subject in public schools in pesantren is inseparable from the curriculum of the national education department. The subject of 
religion is arranged by pesantren itself; e) University, Pesantren Attahdzib already has a university or college that is still a foundation with pesantren.

The Arabic language learning curriculum owned by Pesantren Attahdzib always follows and is in line with the vision and mission set by Pesantren Attahdzib guardians. The vision of Pesantren Attahdzib is "to be a solid pesantren salaf with pillars of noble morals and spiritualemotional-intellectual intelligence". While Pesantren At-ahdzib mission is to "produce a cadre of intellectuals who are "wali" and "wali" who are intellectual".

If one day there is a change in the learning curriculum in Pesantren Attahdzib is always based on the vision and mission and the objectives of pesantren. Curriculum changes in Pesantren Attahdzib often occur in the use of books or learning materials and learning evaluation. When it is felt that the change in curriculum is not in line with the vision and mission of Pesantren Attahdzib, the curriculum will be formulated and discussed again by asatidz and asatidzah (teacher) at plenary meetings and submitted to pesantren guardians.

\section{The Process of Implementing Education Curriculum at Pesantren Attahdzib}

Generally, the education/learning system established in pesantren Attahdzib are devided into 2 types, namely: 1) Diniyah education and 2) Formal education. These two types of education are supported by extra-curricular activities, including life skills.

\section{a. Diniyah Education and Wajar Dikdas}

Diniyah education is an education package that studies the religious sciences, especially kitab kuning. For the success of this education, pesantren guardians are assisted by Ustadz and Ustadzah who are experts in their respective fields following the education curriculum that has been prepared.

In addition to the Diniyah education activities at night, daytime education is also added which is mandatory for students who do not attend formal school, where the daytime education curriculum is combined with the Basic Education Program Wajar Dikdas (Wajib Belajar Pendidikan Dasar) (compulsory basic education) following the curriculum of the Indonesian national education department.

In this diniyah education class levels are starting from Murobel class which are intended for children, Mufradat class for the most basic students, Isti'dad class for elementary students who will enter first-grade class to sixth-grade student. The method is used in pesantren Attahdzib which is the same method used by pesantren salaf in general. Diniyah recitation activities are carried out after Magrib prayer which is completed by 3 hours of subjects following their respective class schedules. In addition to recitation at night, there is also a morning recitation which is filled with Al-Quran recitation both in their rooms and continued with the teacher.

For the success diniyah education, Pesantren Attahdzib is known as the "takror" which is an in-depth discussion about subject matter that is guided by the students of each class in turn with the subject matter of discussion that has been taught by the teacher. If the problems that arise in takror forum cannot be solved, then the problem is conveyed to the teacher who deals with it at the next meeting (Budi, 2020).

\section{b. Formal Education}

Formal education is the level of education from Madrasah Tsanawiyah to university. The learning methods are generally not different from other formal schools, except for local content lessons in the education curriculum following the vision and mission of Pesantren Attahdzib.

The formal educations under the IHSANIAT foundation "Ikatan Hikmah Santri Alumni AtTahdzib" always follow the activities of pesantren and try to always go hand in hand with the existing curriculum at Pesantren At-Tahdzib. Ihsanniat education foundation oversees the formal education institution Madrasah Tsanawiyah (MTs) Ihsanniat, and then to accommodate graduates of MTs students in 1998 Madrasah Aliyah (MA) Ihsanniat was established. Due to the development of Pesantren Atathdzib in 2003, SMK Ihsanniat and Sekolah Tinggi Islam Ihsanniat 


\section{Arabi : Journal of Arabic Studies}

(STAIA) were established. In 2013 SMP Islam Terpadu Ihsanniat was established (Ach. Dzaky GF, 2012).

c. The Material of Kajian Kitab

Following the label "Salafy" which is attached to the name of Pesantren At-Tahdzib, the material subject in Pesantren Attahdzib is based on kitab-kitab salaf (kitab kuning). Pesantren AtTahdzib teaches several Islamic disciplines such as Tafsir, Hadits, Fiqh, Tasawwuf, AqidahAkhlaq, Ilmu alat/Instrumentals (Nahwu-Sharaf), Balaghah, Mantiq (Logic), Faraidl (ilmu waris), 'Arudl, etc.

\section{d. Pesantren Activities Program}

1) Recitation of night diniyah;

2) Recitation of daytime diniyah;

3) Extra recitation of kitab kuning,

4) Implementation of Wajar Dikdas,

5) Speech practice: Indonesian, Javanese, and Arabic;

6) 'ubudiyah practicum;

7) Qira'ah, Dziba'iyyah, and Barzanji;

8) Mujahadah (Dzikir);

9) Ra'an (community service);

10) Jam'iyah Ath-Thalabah (Santri Association);

11) Qari' al-Qur'an Development Program;

12) Life skills (life skills training) in the fields of fisheries, carpentry, agriculture, ranch, sewing, etc.

\section{e. Spiritual Galvanization and Formation of $A$ khlak(Morals)}

Spiritual galvanization is a spiritual activity to manifest spiritual aspects following the vision and mission of Pesantren Attahdzib. This activity, called Mujahadah, is carried out routinely and intensively. The implementation is after each fardlu praying and certain moments following the predetermined mujahadah calendar. The categories include mujahadah of intelligence, security, business success, etc. Besides, with its salafiyah principle, Pesantren Attahdzib upholds the values of noble morals and this is used as a foundation for fostering the behavior of its students so that they truly become human beings of noble morality. The values of unggah-ungguh (politeness) are used as the spirit in the traditions of everyday life.

The values of noble morals are placed in salafiyah values of Pesantren Attahdzib which include values: faith, courtesy, honesty, simplicity, blessing, perseverance, togetherness, concern, sincerity, patience, and trust in Allah Swt.

\section{f. Imtihan (Evaluation)}

Like a formal pesantren school or formal education institution, evaluation of learning outcomes in Pesantren Attahdzib is routinely carried out twice a year or called Imtihan (exam). There are two exams, namely oral/practical and written exams.

1. Oral exam/practice consist of:

a) Imtihan Muhadhah (memorizing), includes Tasrifiyah fi sorfi, Muhafadzhatu asShibyan, Jurumiyah, 'Imrithi, al-Fiyah, and Jauharul Maknun. Those are the conditions to follow the final exam according to the level/class;

b) Imtihan qira'atil kutub (kitab kuning reading test), which was held for three days with the hope to provide an evaluation of the students' mastery in the field of reading kitab kuning without meaning accompanied by understanding ilmu alat (nahwu and sharaf). Imtihan is held before the written test and is applied for the third grade or imrithi class.

c) Imtihan khitabiyyah, speech test using three languages, Indonesian, Javanese, and Arabic. In this test, each is obliged to provide two people who will speak on the 
podium and watched by all students. Assessment in this test is done by ustadz/ustadzah (teacher) who responsible as judges.

1) Indonesian speech is for mufradat class, isti'dad, I, II, III;

2) Javanese speech is for fourth and fifth-grade students;

3) Arabic speech is for sixth-grade students (awwal and tsani).

2. Imtihan (beginning/final) written exams conducted by giving questions about subject matter according to the field.

\section{The Problematics Implementation of Pesantren Attahdzib Curriculum}

Problems that often encountered in the implementation of Pesantren Attahdzib are:

a. Imtihan muhafadzhah (memorizing)

It is a requirement to follow Imtihan II (final exam) following each level/class. But many students of Pesantren Attahdzib lacked interest and ability to fulfill these demands. This problem often arises at the end of each school year.

b. Teacher

Less professional teachers become the lack of optimal curriculum implementation in Pesantren Attahdzib. This is influenced by the change of administrators every year and is accompanied by curriculum changes that are sometimes not suitable for the existing teaching staff. Some teachers live outside the pesantren area and don't maintain discipline in the implementation of teaching and learning activities in pesantren.

c. Learning time

The implementation of teaching and learning activities in the Pesantren Attahdzib which is carried out at night can cause problems of students' lack of concentration due to busy activities during the day. This happens to students who are still lacking discipline in managing the time between formal education activities that are carried out during the day. The solution to this problem is that every formal education activity other than teaching and learning activities must first ask permission from pesantren administrators so that these extra activities don't disturb the pesantren learning activities carried out at night.

Those problems mentioned can be overcome by implementing regulations that emphasize more discipline, as well as more precise timing to optimize the teaching and learning activities both in formal schools and pesantren without beating each other.

\section{Conclusion}

Curriculum is indeed not very well known in the world of pesantren, even though the material already exists in the practice of teaching, spiritual guidance, and training skills in daily life at pesantren. The curriculum at pesantren salafiyah is not in the form of syllabus description but in the form of funun books that are taught to students. The books used are usually kitab kuning or kutub al-salaf. The method established in Pesantren Attahdzib is the same as most other salafiyah pesantren, namely: sorogan, bandungan or wetonan, and memorizing.

There learning systems established in pesantren Attahdzib are: 1) Diniyah education and 2) Formal education. These two types of education are supported by extra-curricular activities including life skills. Diniyah education is an education package that studies the religious sciences, especially kitab kuning. For the success of this education, pesantren guardians are assisted by Ustadz and Ustadzah who are experts in their respective fields following the education curriculum that has been prepared. Formal education is the level of education from Madrasah Tsanawiyah to university. The learning methods are generally not different from other formal schools, except for local content lessons in the education curriculum following the vision and mission of Pesantren Attahdzib.

The problems faced in its implementation included some teachers' disciplinary problems, the learning evaluation that sometimes considered hard and a burden on students, and the formal 


\section{Arabi : Journal of Arabic Studies}

schools' extra-activities that sometimes obstruct the teaching and learning process in pesantren. Those problems can be overcome by implementing regulations that emphasize more discipline, as well as more precise timing to optimize the teaching and learning activities both in formal schools and pesantren without beating each other.[]

\section{References}

Abdurrahman. 2017. "Implementasi Manajemen Kurikulum Pesantren Berbasis Pendidikan Karakter", At-Turas, Vol. 4, No. 2.

Albantani, Azkia Muharom. \& Ahmad Madkur. "Think globally, act locally: the strategy of incorporating local wisdom in foreign language teaching in Indonesia", International Journal of Applied Linguistics and English Literature, Vol. 7, No. 2.

Ali, A. Mukti. 1987. Beberapa Persoalan Agama Dewasa ini. Jakarta: Rajawali Press.

Ali, Mohammad. 2009. Filsafat Pendidikan Islam. Jakarta: Departemen Agama RI.

Azizi, Qodri A. 2000. Islam dan Permasalahan Sosial. Yogyakarta: LKIS.

Basri, Hasan. 2009. Filsafat Pendidikan Islam. Bandung: Pustaka Setia.

Budi. "Pesantren Attahdzib Jombang”, https://www.laduni.id/ accessed March 27, 2020.

Daulay, Haidar Putra. 2001. Historisitas dan Eksistensi: Pesantren, Sekolah dan Madrasah. Yogyakarta: Tiara Wacana.

Dhofier, Zamakhsyari. 1982. Tradisi Pesantren. Jakarta: LP3ES.

GF, Ach. Dzaky. "Yayasan Pendidikan Ihsanniyat", https://smkihsanniat.wordpress.com/ accessed March 27, 2020.

Habibi, Burhan Yusuf. 2019. "Integrasi Kurikulum Bahasa Arab Pesantren Tradisional dan Modern di Madrasah Aliyah Program Keagamaan”, Arabi: Journal of Arabic Studies, Vol. 4, No. 2.

Hajjaj, Wafi Ali. 2017. "Pengembangan Kurikulum Pesantren Pelajar: Studi Empirik di Pesantren Pelajar Islam (PPI) Nurul Burhan Bondowoso", Tarbiyatuna, Vol. 10, No. 2.

Hanun, Asrohah. 1999. Sejarah Pendidikan Islam. Jakarta: PT. Logos Wacana Ilmu.

Himmah, Ro'fat Hizmatul. Muhammad Afif Amrulloh. 2017. "Pengembangan Kurikulum Bahasa Arab Pesantren Mu'adalah", Al Bayan, Vol. 9, No. 2.

Ma'arif, Muhammad Anas. \& Muhammad Husnur Rofiq. 2018. "Pola Pengembangan Kurikulum Pendidikan Pesantren Berkarakter: Studi Implementasi Pendidikan Berkarakter di Pondok Pesantren Nurul Ummah Mojokerto", Tadris, Vol. 13, No. 1.

Madjid, Nurcholish. 1985. Merumuskan kembali Tujuan Pendidikan Pesantren dalam Dawam Rahardjo, Pergulatan Dunia Pesantren: Membangun dari Bawah. Jakarta: P3M.

Mastuhu. 1988. Prinsip Pendidikan Pesantren. Jakarta: P3M.

Nasution, S. 1995. Kurikulum dan Pengajaran. Jakarta: Bumi Aksara.

Nizar, Ramayuis dan Samsul. 2009. Filsafat Pendidikan Islam: Telaah Sistem Pendidikan dan Pemikiran Para Tokohnya. Jakarta: Kalam Mulia.

Qomar, Mujamil. 2009. Pesantren dari Transformasi Metodologi menuju Demokratisasi Institusi. Jakarta: Erlangga.

Rahardjo, M. Dawan. 1988. Pesantren dan Pembaharuan. Jakarta: LP3ES. 
Arabi : Journal of Arabic Studies

Rohman, Miftahur. 2018. "Pembelajaran Bahasa Arab di Madrasah Aliyah dalam Perspektif Kurikulum 2013", An-Nabighoh, Vol. 20, No. 2.

Roviin. 2018. "Pengembangan Kurikulum Bahasa Arab di Madrasah", Tarling, Vol. 1, No. 2.

Saifuddin, Ahmad. 2015. "Eksistensi Kurikulum Pesantren dan Kebijakan Pendidikan", Jurnal Pendidikan Agama Islam, Vol. 3, No.1.

Saifuddin, Ahmad. 2016. Eksistensi Kurikulum Pesantren dan Kebijakan Pendidikan. Nganjuk: STAI Darussalam Krempyang Nganjuk.

Salamah. 2016. Pengembangan Model Kurikulum Holistik Pendidikan Agama Islam pada Madrasah Tsanawiyah. Yogyakarta: Aswaja Pressindo.

Thohir, Kholis. 2017. "Kurikulum dan Sistem Pembelajaran Pondok Pesantren Salafi di Kecamatan Kresek Kabupaten Tangerang Provinsi Banten”, Analytica Islamica, Vol. 6, No. 1.

Tsuroyya, Elfa. 2017. "Manajemen Kurikulum Pesantren Berbasis Madarasah di MAN 3 Sleman Yogyakarta", Manageria, Vol. 2, No. 2.

Wahab, Muhbib Abdul. 2016. "Standarisasi Kurikulum Pendidikan Bahasa Arab di Perguruan Tinggi Keagamaan Islam Negeri", Arabiyat: Jurnal Pendidikan Bahasa Arab dan Kebahasaaraban, Vol. 3, No. 1. 